than the adjudication of interests in tangible goods, wherein states may cut off nonresidents' interests with no actual notification. ${ }^{33}$ Furthermore, witnesses to transactions between nonresidents and residents are more likely to live in the state which the nonresident entered.

It would be difficult for corporations or individuals to defend in distant jurisdictions where they might have no agents, office, or other organization. But if the Maryland type of jurisdiction were to be sustained, the courts would still retain their discretionary power on pleas of forum non conveniens to prevent hardship on nonresident defendants. ${ }^{34}$ This basis for jurisdiction over nonresidents might increase their costs of defense, for it can be foreseen that a goodsized, active corporation or other business would possibly be forced to defend many claims in various jurisdictions. The hardship would certainly not be greater, however, than that which arises from the well-established right to sue a corporation doing business in the forum upon causes of action which are totally unconnected with it. In addition, it seems reasonable to require the public to share the social cost ${ }^{35}$ of enterprise by paying higher prices for the goods and services produced by businesses operating across state boundaries. ${ }^{36}$

This system of jurisdiction would leave unsolved the problem of protecting nonresidents from plaintiffs who obtain default judgments on unfounded claims, which the nonresident considers not worthy of defending. It does not resolve the difficulty of the successful plaintiff who finds that the defendant has no property within the jurisdiction. But it probably is simpler and less expensive for such plaintiffs to enforce judgments in another jurisdiction than it is to travel to other jurisdictions to try their cases upon the merits.

In view of the large volume of enterprise carried on across state boundaries the future may see increasing state jurisdiction over nonresident defendants under statutes similar to the Maryland statute construed in Johns v. Bay State Abrasive Products Co., consistent, of course, with the constitutional doctrine set out in International Shoe Co. v. Washington. ${ }^{37}$

\title{
ACCESS PROBLEMS IN STRATIFIED ESTATES
}

Division of the earth's subsurface into separate strata of ownership has raised special problems in the law of property. One type of controversy results

33 Anderson National Bank v. Luckett, 32I U.S. 233 (x944); Security Savings Bank v. California, 263 U.S. 282 (I923).

34 In Leet v. Union Pacific R. Co., 25 Cal. 2d 605, I55 P. 2d 42 (I944), cert. denied 325 U.S. 866 (I945), the court described forum non conveniens as being an equitable rule embracing the discretionary power of a court to decline to exercise jurisdiction which it has over a cause of action where it believes that the action may be more appropriately and justly tried elsewhere.

${ }^{35}$ Social cost being the cost of adjudicating claims between residents and enterprises resident in distant jurisdictions.

${ }^{36}$ Adopting in part the rationale given by Justice Douglas for the existence in our law of vicarious liability without fault in his article Vicarious Liability and Administration of Risk, 38 Yale L.J. 584 (I929).

${ }^{37} 326$ U.S. 3 I0 (I945). 
from the conveyance of subterranean coal without a reservation of access to 'the estate below. When the grantor has later sought to drill through the coal, the courts have been faced with these opposing interests: the coal owner's desire to receive the unencumbered property he has bargained for; and the surface owner's claim that his retained estate beneath the coal should not be withdrawn from use. The latter interest has generally carried the day, but the reasoning and remedy employed have varied.

In the leading case of Chartiers Block Coal Co. ข. Mellon ${ }^{\mathrm{I}}$ there were advanced two of the doctrines relied upon in this field. The coal owner had sought to enjoin the surface owner's lessee from drilling through the coal to the oil beneath. Looking at the importance of the oil and gas industries to the economy of Pennsylvania, the court concluded that such a valuable estate should not be withdrawn from exploitation, and denied the injunction. A concurring opinion $^{2}$ placed the decision on a much broader basis, stating that since the need of access to a lower stratum was as much the work of nature as the need of support to an upper stratum, the earth's strata should be considered subject to "reciprocal servitudes" of access and support. ${ }^{3}$ The opinions differed in another respect. The former considered that the coal owner would still have a remedy at law; 4 the latter did not see how the exercise of a right of access could subject its owner to damages. However, they joined in rejecting the trial court's reasoning that the surface owner had a way of necessity to the estate below the coal. 5

Nevertheless, in the recent case of Pyramid Coal Co. v. Pratt the way of necessity doctrine was employed to deny access to water. The coal under a twenty-five acre tract had been conveyed to the defendant's predecessor in title. The surface owner then subdivided, conveying two acres to the plaintiff who drilled a well to obtain water for domestic use. Twelve years later the defendant in mining the coal removed part of the casing, and the subdivision owner sued for damages. Applying the rule that the necessity must exist at

I52 Pa. 286, 25 Atl. 597 ( 1893 ).

I Ibid., at 299 and 600.

3 This solving phrase has influenced later opinions, e.g., Telford v. Jennings Products Co., 203 Fed. 456 (C.A. 7th, 19I3); Chartiers Oil Co. v. Curtiss, 34 Ohio C.C. I06 (IgrI). In 3 Lindley on Mines $\S 827$ (3d ed., I9I4), the author states: "This concurring opinion 'snaps like a whip.' Its force and logic are irresistible." But consult Simonton, Ways by Necessity, 25 Col. L. Rev. 57r, 592 (r925), for an effective criticism of the "reciprocal servitudes" approach.

$4 \mathrm{It}$ is curious to note that the first decision in this field, Jefferson Iron Works v. Gill Brothers, 9 Ohio Dec. 48I (1885), contemplated a directly opposite result. Using irreparable damage as a basis, the court enjoined drilling for gas because of the dangers which would result from its escape into the mine, but stated that should the injury be direct only (as in the case of water), the coal owner would have adequate remedy at law.

Since this case, fears of escaping gas have been largely discounted. Consult concurring opinion in Chartiers Block Coal Co. v. Mellon, I52 Pa. 286, 302, 25 Atl. 597, 601 (1893).

5 The court in Chartiers Oil Co. v. Curtiss, 34 Ohio C.C. Io6 (Igrr), while admitting an analogy, also denied that the way of necessity doctrine could be applied to the subsurface without modification. See note 7 infra.

${ }^{6} 92$ N.E. 2 d 858 (Ind. App., I95o), noted 36 Va. I. Rev. 960 (1950), I2 U. of Pitt. L. Rev. II9 (I950). 
the time of the severing of the servient from the dominant estate, the court denied relief because the plaintiff had not proved that the original twenty-five acre tract was entirely cut off from the water by the coal. ${ }^{7}$ It made clear, however, that such proof would not be required in the case of oil or gas. ${ }^{8}$

The application of the surface doctrine of way of necessity to subsurface conveyances seems an unfortunate extension. In surface cases, necessity is readily ascertainable, while the cost of test drilling or other geological inspection in order to determine whether the water can be reached without passing through the coal may well prove prohibitive.

Furthermore, there has developed the rationale that surface necessity does not create the way but merely supplies evidence of the intent of the parties. 9 There may be times when this reasoning is appropriate. But evidence that no way was intended has on occasion been disregarded, ${ }^{\text {,o }}$ and the averment that

7 Under the surface way of necessity doctrine, if an isolated estate has ever been a part of a larger estate bordering on a public way, then in the conveyance severing this estate there is implied a way over the intervening land to the highway. The unity of ownership of the dominant and servient estates is essential. Bullard v. Harrison, 4 M. \& S. 387 (I9I5); Tracy v. Atherton, 35 Vt. 52 (I862); Ellis v. Blue Mountain Forrest Ass'n, 69 N.H. 385, 4I Atl. 856 (I898). That the isolation arise from the conveyance, and not from subsequent events, is also necessary. Van Patten v. Loof, 349 IIl. 483, I82 N.E. 628 (I932); Cornell-Andrews Smelting Co. v. Boston \& Providence R. Corp., 202 Mass. 585,89 N.E. II 8 (Igog). Where isolation is the result of later transactions by one of the parties, it simply makes sense not to relieve him of the consequences of his own action at the expense of another. See Botsford v. Wallace, 69 Conn. 263, 37 Atl. 902 (1897); Kentucky Distillers \& Warehouse Co. v. Warwick, I66 Ky. 65I, I79 S.W. 6rx (rgI5); Richards v. Attleborough Branch R. Co., I53 Mass. I20, 26 N.E. 4I8 ( $18 \mathrm{gr}$ ). This occurs where one of the owners has subdivided, leaving a portion of his estate with no access. Accordingly, while the use of an existing way of necessity may be increased by subdivision, original or additional ways are not created thereby. Burling v. Leiter, $272 \mathrm{Mich}$. 448, 262 N.W. 388 (I935); see Lankin v. Terwilliger, 22 Ore. 97, 29 Pac. 268 (I892); United States v. Rindge, 208 Fed. 6r I (S.D. Cal., I9I3).

The rule with respect to subdivision of the surface seems proper because it does not operate to withdraw an estate from use. The same cannot be said of its application to the subsurface, as the Pyramid Coal Co. case demonstrates.

${ }^{8}$ Within the doctrine of way of necessity there is no basis for a dictinction between water and oil or gas. In the case of the latter, the surface owner usually seeks to drill several wells, and it has been felt that the frequent statement that only one way of necessity will be granted renders necessity theory inapplicable to oil and gas. See Chartiers Oil Co. v. Curtiss, 34 Ohio C.C. Io6 ( $I 9 x)$. However, it seems safe to say that this rule has never been laid down in a surface case in which use of the whole dominant estate required more than one way. In Nichols v. Iuce, 24 Pick. (Mass.) IO2 (1834), the court recognized that division of the dominant estate by a cliff would lead to more than one way of necessity.

${ }^{9}$ See, e.g., Nichols v. Luce, 24 Pick. (Mass.) I02 (I834); Collins v. Prentice, I5 Conn. $3^{8}$ (1842); Carmon v. Dick, 170 N.C. 305,87 S.E. 224 (1915).

ro Where the dominant owner obtained access by passing over the land of a stranger, thus failing to assert a way of necessity, the courts have treated this as an express easement, not to be lost by mere non-user. Finn v. Williams, 376 Ill. 95, 33 N.E. 2 d 226 (I94r); Adams v. Hodgkins, I09 Me. $36 \mathrm{r}, 84$ Atl. 530 (I9I2). When the dominant owner has been granted access for a limited purpose, way of necessity has been employed to give him another for a broader use. Myers v. Dunn, 49 Conn. 7 I (I88I); Uhl v. Ohio River R. Co., 47 W. Va. 59, 34 S.E. 934 (r889); cf. Condry v. Laurie, I84 Md. 3I7, 4I A. 2d 66 (I944); Contra: Haskell v. Wright, 23 N.J. Eq. 389 ( 1873 ); cf. Baldwin Lumber Co. v. Todd, I24 La. 543, 50 So. 526 (I909); Greek v. Wylie, 266 Pa. 18, rog AtI. 529 (1920).

For an argument that parol evidence should not be admitted to rebut the presumption of intent, see Evidence of Intent As Rebutting Ways of Necessity, 29 Yale L.J. 665 (I920). 
the way is implied purely through a fiction of law in order that no estate be withdrawn from use ${ }^{\mathrm{xI}}$ seems a more realistic exposition of the true rationale. It is likely that the doctrine of surface way of necessity has been carried to the point where, without compensation to the servient owner, it operates oppressively. This objection is doubly cogent in subsurface conveyances, where intent is almost invariably absent. Frequently the parties have disregarded the estate below the coal because its value appeared inconsequential at the time of the conveyance; the presence of oil or gas may not have been known, nor the need for water apparent. In such cases perhaps the best compromise would be to allow the surface owner to drill, but require him to compensate the coal owner for the resulting injury to his estate, as suggested by the court in the Chartiers Coal case.

This solution would demand an unusual exercise of judicial initiative, in view of the constitutional requirement that private property shall not be taken except for "public use." similar situations. Legislation in many states has provided for eminent domain proceedings for private benefit, and in holding them constitutional most courts have been willing to relax the "public use" requirement to the vanishing point. ${ }^{x_{3}}$ A purely judicial development has been the doctrine of "balancing the equities." While equity should grant an injunction against the invasion of a clear property right, it has in some cases refused to do so where the resulting hardship to the dominant owner would greatly exceed the benefit to the servient owner, the latter being remitted to his remedy at law. ${ }^{14}$

II See Buss v. Dyer, I25 Mass. 287 (1878); Hawley v. Chaffee, 88 Vt. 468, 93 Atl. 120 (1914). Accord: Condry v, Laurie, I84 Md. 3I7, 4I A. 2d 66 (I944). In Crotty v. New River \& Pocahontas Consolidated Coal Co., 72 W. Va. 68, 78 S.E. 233 (Igr3), the court went so far as to disregard one of the fixed rules. After going back almost one hundred years to find unity of ownership, it implied the grant of a way to a public road not existent at that time.

sa "[N]or shall private property be taken for public use, without just compensation." U.S. Const. Amend. 5. There is a negative implication that private property shall not be taken for private use, regardless of compensation.

${ }^{23}$ Consult Nichols, The Meaning of Public Use in the Law of Eminent Domain, 20 B.U.L. Rev. 615 (1940); The Public Use Limitation on Eminent Domain: An Advance Requiem, 58 Yale L.J. 599 (I949). One method of evasion is the view that it is sufficient that the public have a theoretical right to use the property taken. Nichols, op. cit. supra, at 62I-22. Construction of a private road has also been approved on the ground that it enabled its user to leave his home to vote and serve on juries. Robinson v. Swope, I2 Bush. (Ky.) 2I (I876); Brewer v. Bowman, $9 \mathrm{Ga} .37$ ( $185^{\circ}$ ). State constitutions providing that exploitation of resources is a public use have been upheld by the Supreme Court. Clark v. Nash, r98 U.S. 36I (Ig05); O'Neill v. Leamer, 239 U.S. 244 (I9I5); Strickley v. Highland Boy Gold Mining Co., 200 U.S. 527 (rgo6).

${ }_{4}$ Consult McClintock, Discretion to Deny Injunction Against Trespass and Nuisance, I2 Minn. L. Rev. 565 ( 1928 ); for an argument in favor of the extension of this doctrine, see Keeton and Morris, Notes on "Balancing the Equities," I8 Texas L. Rev. 4I2 (I940). The principal application has been in cases of innocent encroachment by the building of an adjoining landowner. E.g., Lynch v. Union Institute for Savings, I59 Mass. 306, 34 N.E. 364 (r893); Methodist Episcopal Society v. Akers, I67 Mass. 560, 46 N.E. 38I (I897); Crocker v. Manhat$\tan$ Life Ins. Co., 6I App. Div. 226, 7o N.Y. Supp. 492 (Ist Dep't, Igor). Here the courts are often motivated by a reluctance to help a plaintiff who is simply trying to make a good thing of his rights. See Lynch v. Union Institute for Savings, supra; Hunter v. Carroll, 64 N.H. 572, I5 
In the situation of the principal case, with no judicial equivalent of an eminent domain procedure available to alleviate the necessity of finding that the surface owner has either an unqualified right or no right at all to drill through the coal, ${ }^{15}$ it is not strange to find the Indiana court resorting to an arbitrary distinction between water and oil or gas in its attempt to balance the competing interests. The court was unwilling to give general application to a rationale evoked by a concern for the oil and gas industries of Pennsylvania ${ }^{16}$ - the equivalent of finding for the surface owner in Pyramid Coal Co. v. Pratt.

\section{"PUBLIC INTEREST" AND THE MARKET IN COLOR TELEVISION REGULATION*}

Color television is not a new idea in the history of television and the problem had been before the Federal Communications Commission as early as I940. The Commission considered various color television systems in public hearings in I94I, I944-45, and between December 3, I946 and February I3, I947, but refused to adopt commercial standards for any of the systems demonstrated because they were unsatisfactory. On July II, I949 the Commission issued a notice of further proposed rule-making relative to color television. ${ }^{2}$ The color television systems which the Commission proposed to examine had to meet two criteria: ( $\mathrm{I}$ ) that they operate in a six megacycle channel and (2) that the pictures could be received on existing black and white television receivers

Atl. I7 (I888); Tramonte v. Colarusso, 256 Mass. 299, I52 N.E. go (1926). The doctrine has not been extended to intentional, or negligent, crossing of property lines. Curtis $\mathrm{Mfg}$. Co. v. Spencer Wire Co., 203 Mass. 448, 89 N.E. 534 (Igo9); Szathmary v. Boston \& A. R. Co., 214 Mass. 42, I00 N.E. IIO7 (rg03); Kershishian v. Johnson, 210 Mass. I35, 96 N.E. 56 (IgIr). In other cases of intentional trespass, where the loss to the defendant would be exceptional and that to the plaintiff negligible, equity has denied an injunction. Crescent Mining Co. v. Silver King Mining Co., I7 Utah 444, 54 Pac. 244 (I898); McCann v. Chasm Power Co., 2II N.Y. 30x, I05 N.E. 4 I6 (I9I4).

Is For "balancing the equities" to be applicable, the coal owner would have to be seeking an injunction against drilling by the surface owner. Even then the doctrine has not been employed where there was substantial injury caused by intentional trespass. Barker v. Mintz, 73 Colo. 262, 215 Pac. 534 (r923), and Whiles v. Grand Junction Mining \& Fuel Co., 86 Colo. 4I8, 282 Pac. 260 ( $x 929)$ relied upon a statute which provided that a surface owner could enjoin the mineral owner from mining unless the latter gave the former a bond to secure him against injury.

${ }^{16}$ In Pennsylvania Central Brewing Co. v. Lehigh Valley Coal Co., 250 Pa. 300 , 95 Atl. 47I (I9I5), the Pennsylvania court did extend the Chartiers Coal decision to subterranean water.

I FCC, First Report of Commission, Color Television Issues, IT 7-2r (r950) (mimeographed). (The First Report of Commission, Color Television Issues will hereinafter be cited as "First Report.")

2 FCC, Television Broadcast Service, Notice of Further Proposed Rule Making, I4 Fed. Reg. 4483 (I949).

* Since this issue went to press, the Supreme Court has handed down its decision in the current case. Radio Corp. of America v. United States, 19 U.S. L.W. 4337 (May 29, 195I). As suggested in this Comment the lower court decision was affirmed. Justice Frankfurter dissented on substantive grounds. 